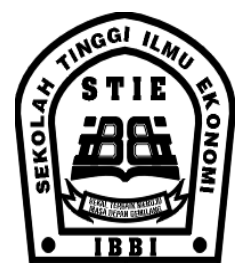

\title{
PENGARUH MOTIVASI KERJA DAN KOMUNIKASI TERHADAP KINERJA KARYAWAN PADA PT. INDODACIN PRESISI UTAMA MEDAN
}

\author{
Stefanie Yuda, Junaidi Hasan
}

\begin{abstract}
ABSTRAK
Berdasarkan data PT. Indodacin Presisi Utama Medan bahwa selama selama tahun 2013 sampai tahun 2016 terjadi penurunan penjualan timbangan. Penurunan penjualan timbangan ini dari tahun 2013 sampai tahun 2016 sebanyak 91.502 unit tentunya berdampak pada pengurangan keuntungan berkaitan dengan rendahnya kinerja karyawan yang diduga karena motivasi kerja rendah dan komunikasi antar karyawan yang kurang baik. Penelitian ini bertujuan untuk mengetahui pengaruh motivasi kerja dan komunikasi terhadap kinerja karyawan pada PT. Indodacin Presisi Utama Medan.

Metode yang digunakan dalam metode penelitian deskriptif kuantitatif. Populasi dan sampel dalam penelitian ini adalah semua karyawan berjumlah 42 orang karyawan yang terdiri dari karyawan di kantor dan teknisi PT Indodacin Presisi Utama Medan. Pengujian data menggunakan uji asumsi klasik, analisis regresi linear berganda, uji f, uji t dan koefisien determinasi.

Hasil penelitian menunjukkan bahwa secara parsial, dapat diketahui bahwa motivasi kerja dan komunikasi berpengaruh signifikan terhadap kinerja karyawan. Dan secara simultan, motivasi kerja dan komunikasi berpengaruh signifikan terhadap kinerja karyawan. Besarnya koefisien determinasi dilihat dari Adjusted $R$ Square sebesar 81,4\%. Sedangkan sisanya sebesar 18,6\% merupakan variabel bebas lain yang tidak diteliti dalam penelitian ini seperti disiplin kerja dan pelatihan kerja.

Kesimpulan menyatakan bahwa motivasi kerja dan komunikasi berpengaruh signifikan terhadap kinerja karyawan pada PT. Indodacin Presisi Utama Medan secara parsial dan simultan.
\end{abstract}

\section{Kata Kunci : Motivasi Kerja, Komunikasi, Kinerja Karyawan}

\section{PENDAHULUAN}

Peningkatan kinerja karyawan memberikan dampak positif dalam pencapaian tujuan perusahaan maka oleh sebab itu manajemen harus terlebih dahulu menciptakan kinerja karyawan yang baik. Menciptakan kinerja karyawan yang baik adalah tidak mudah karena kinerja karyawan dapat tercipta apabila variabel-variabel yang mempengaruhinya seperti motivasi kerja dan komunikasi dapat berjalan dengan baik di dalam suatu perusahaan.

Motivasi merupakan salah satu faktor yang dapat mempengaruhi kinerja karyawan di dalam perusahaan. Motivasi adalah faktor yang dapat menggerakkan seseorang untuk mempunyai keinginan dan kesediaan bekerja. Karyawan yang termotivasi dalam melaksanakan pekerjaannya, menganggap bahwa tugas mereka adalah tantangan yang harus diselesaikan. Karyawan yang tidak termotivasi maka kinerjanya tidak dapat maksimal dan tujuan perusahaan tidak dapat tercapai.

Komunikasi sangat penting bagi seluruh fungsi perusahaan, karena sistem operasional dan manajemen digerakkan oleh komunikasi. Perusahaan harus mampu menaungi kegiatan antar karyawan dalam pengerjaan tugasnya. Komunikasi yang efektif yang terjalin dapat ditunjukan dengan peningkatan kinerja karyawan karena telah berhasil menunjukan kerjasama yang baik.

PT. Indodacin Presisi Utama merupakan salah satu perusahaan manufaktur yang bergerak dalam bidang perakitan timbangan dan purna jual. PT. Indodacin Presisi Utama Medan mulai memproduksi timbangan jembatan dengan sistem mekanik, yang telah dipasarkan dan dikenal sampai saat ini di Indonesia dari Sabang sampai Merauke. Dengan luasnya jangkauan PT. Indodacin 


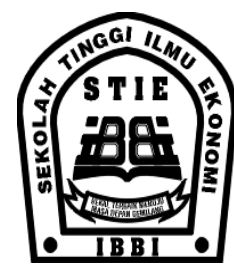

Presisi Utama Medan seharusnya mampu menghasilkan keuntungan yang besar. Akan tetapi kenyataannya pada tahun 2013 sampai dengan 2016 di Sumatera Utara, penjualan alat-alat timbangan justru mengalami penurunan dimana hal ini dapat terlihat di Tabel 1.

\section{Tabel 1}

Data Penjualan Alat-Alat Timbangan PT. Indodacin Presisi Utama Medan Yang Terjadi Selama Tahun 2013 Sampai Dengan Tahun 2016

\begin{tabular}{|c|c|c|}
\hline Tahun & Penjualan (unit) & Selisih (\%) \\
\hline 2013 & 413.750 & - \\
\hline 2014 & 388.991 & $-5,98 \%$ \\
\hline 2015 & 355.113 & $-8,71 \%$ \\
\hline 2016 & 322.248 & $-9,25 \%$ \\
\hline
\end{tabular}

Sumber : PT. Indodacin Presisi Utama Medan, 2017

Tabel 1 di atas dapat diketahui bahwa adanya penurunan penjualan timbangan yang terjadi di PT. Indodacin Presisi Utama Medan selama tahun 2013 sampai tahun 2016. Penurunan penjualan timbangan ini dari tahun 2012 sampai tahun 2016 sebanyak 91.502 unit tentunya berdampak pada pengurangan keuntungan yang dikarenakan adanya motivasi kerja yang rendah dan komunikasi antar karyawan yang kurang baik.

Berdasarkan observasi di PT. Indodacin Presisi Utama Medan, peneliti menemukan masalah motivasi kerja yang dapat dilihat pada data prestasi kerja karyawan di PT. Indodacin Presisi Utama Medan selama satu tahun terakhir.

Tabel 2

Data Prestasi Kerja Karyawan PT. Indodacin Presisi Utama Medan Yang Terjadi Selama Tahun 2016 (Januari Desember)

\begin{tabular}{|c|c|c|c|}
\hline Bulan & $\begin{array}{c}\text { Penjualan } \\
\text { (Unit) }\end{array}$ & $\begin{array}{c}\text { Target } \\
\text { Penjualan } \\
\text { Perusahaan } \\
\text { (Unit) }\end{array}$ & $\begin{array}{c}\text { Persentase } \\
(\%)\end{array}$ \\
\hline Jan 2016 & 29.340 & 30.000 & $97,80 \%$ \\
\hline Feb 2016 & 29.134 & 30.000 & $97,11 \%$ \\
\hline Mar 2016 & 28.410 & 30.000 & $94,70 \%$ \\
\hline Apr 2016 & 28.315 & 30.000 & $94,38 \%$ \\
\hline Mei 2016 & 26.114 & 30.000 & $87,05 \%$ \\
\hline Juni 2016 & 26.011 & 30.000 & $86,70 \%$ \\
\hline Juli 2016 & 25.735 & 30.000 & $85,78 \%$ \\
\hline Agus 2016 & 25.475 & 30.000 & $84,92 \%$ \\
\hline Sept 2016 & 25.081 & 30.000 & $83,60 \%$ \\
\hline
\end{tabular}

\begin{tabular}{|c|c|c|c|}
\hline Okt 2016 & 27.176 & 30.000 & $90,59 \%$ \\
\hline Nov 2016 & 25.767 & 30.000 & $85,89 \%$ \\
\hline Des 2016 & 25.690 & 30.000 & $85,63 \%$ \\
\hline
\end{tabular}

Sumber : PT. Indodacin Presisi Utama Medan, 2017

Tabel 2 di atas dapat diketahui bahwa adanya penurunan prestasi kerja dalam menjual timbangan di PT. Indodacin Presisi Utama Medan dari bulan Januari 2016 sampai dengan Desember 2016. Penurunan penjualan timbangan ini pada akhir tahun 2016 sebanyak 3.650 unit ini dari penjualan bulan Januari tahun 2016 sampai dengan penjualan bulan Desember tahun 2016 dikarenakan masalah motivasi kerja. Fenomena masalah motivasi kerja ini dikarenakan karyawan merasa tidak adanya kesempatan untuk mendapatkan promosi jabatan sehingga kualitas kerja karyawan menjadi menurun, karyawan kurang merasa tertantang dengan pekerjaan yang diberikan dari perusahaan sehingga karyawan tidak bersemangat untuk menyelesaikan pekerjaan tepat waktu, dan kurangnya tanggung jawab karyawan terhadap pekerjaan yang dijalaninya sehingga karyawan tidak dapat berkerja sama dengan baik dengan karyawan lain dalam menyelesaikan pekerjaan.

Sedangkan fenomena masalah komunikasi yang menyebabkan menurunnya kinerja karyawan yaitu pimpinan tidak menjelaskan pekerjaan yang akan dikerjakan karyawan sehingga kualitas kerja karyawan menurun dan pesan yang disampaikan oleh pimpinan kepada karyawan masih belum benar dan akurat sehingga karyawan tidak mampu menyelesaikan pekerjaan tepat waktu.

Berdasarkan hal tersebut maka peneliti tertarik untuk membahasnya dalam bentuk proposal yang berjudul Pengaruh Motivasi Kerja dan Komunikasi Terhadap Kinerja Karyawan Pada PT. Indodacin Presisi Utama Medan.

Berdasarkan latar belakang yang telah diuraikan sebelumnya, maka identifikasi masalah yang menyebabkan menurunnya kinerja karyawan adalah :

1. Teridentifikasi bahwa karyawan merasa tidak adanya kesempatan untuk mendapatkan promosi jabatan sehingga kualitas kerja karyawan menjadi menurun.

2. Teridentifikasi bahwa karyawan kurang 


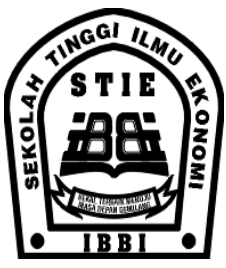

merasa tertantang dengan pekerjaan yang diberikan dari perusahaan sehingga karyawan tidak bersemangat untuk menyelesaikan pekerjaan tepat waktu.

3. Teridentifikasi bahwa kurangnya tanggung jawab karyawan terhadap pekerjaan yang dijalaninya sehingga karyawan tidak dapat berkerja sama dengan baik dengan karyawan lain dalam menyelesaikan pekerjaan..

4. Teridentifikasi bahwa pimpinan tidak menjelaskan pekerjaan yang akan dikerjakan karyawan sehingga kualitas kerja karyawan menurun.

5. Teridentifikasi bahwa pesan yang disampaikan oleh pimpinan kepada karyawan masih belum benar dan akurat sehingga karyawan tidak mampu menyelesaikan pekerjaan tepat waktu.

Berdasarkan identifikasi dan

pembatasan masalah tersebut, maka rumusan permasalahan ini sebagai berikut :

1. Apakah terdapat pengaruh motivasi kerja terhadap kinerja karyawan pada PT. Indodacin Presisi Utama Medan?

2. Apakah terdapat pengaruh komunikasi terhadap kinerja karyawan pada PT. Indodacin Presisi Utama Medan?

3. Apakah terdapat pengaruh motivasi kerja dan komunikasi terhadap kinerja karyawan pada PT. Indodacin Presisi Utama Medan?

Berdasarkan rumusan masalah di atas, penelitian ini dilakukan dengan tujuan sebagai berikut :

1. Untuk mengetahui pengaruh motivasi kerja terhadap kinerja karyawan pada PT. Indodacin Presisi Utama Medan.

2. Untuk mengetahui pengaruh komunikasi terhadap kinerja karyawan pada PT. Indodacin Presisi Utama Medan.

3. Untuk mengetahui pengaruh motivasi kerja dan komunikasi terhadap kinerja karyawan pada PT. Indodacin Presisi Utama Medan.

\section{TINJAUAN LITERATUR}

\section{Manajemen Sumber Daya Manusia}

Di dalam suatu organisasi pengelolaan yang baik pada manajemen sumber daya manusia sangat penting. Hal ini mengingat pegawai merupakan asset perusahaan yang wajib dijaga. Dengan semakin berkembangnya suatu organisasi maka makin sulit pula perencanaan dan pengendalian pegawainya. Menurut Hasibuan (2012 : 22), Manajemen Sumber Daya Manusia adalah Ilmu dan seni dalam mengatur proses hubungan dan proses tenaga kerja agar efektif dan efisien serta membantu terwujudnya tujuan perusahaan, pegawai, dan masyarakat. Menurut

Hasibuan (2012 : 21) fungsi-fungsi Manajemen Sumber Daya Manusia, meliputi :

1. Perencanaan

2. Pengorganisasian

3. Pengarahan

4. Pengendalian

5. Pengadaan

6. Pengembangan

7. Kompensasi

8. Pengintegrasian

9. Pemeliharaan

10. Kedisiplinan

11. Pemberhentian

\section{Motivasi Kerja}

Motivasi berasal dari kata latin movere yang berarti dorongan atau daya penggerak. Menurut Hasibuan (2012 : 141), Motivasi yaitu bagaimana caranya mendorong gairah kerja bawahan agar mereka mau bekerja keras dengan memberikan semua kemampuan dan keterampilannya untuk mewujudkan tujuan organisasi. Motivasi sangat penting karena dengan motivasi ini diharapkan setiap karyawan mau bekerja keras dan antusias untuk mencapai produktivitas yang tinggi.

Menurut Hasibuan (2012 : 146), ada beberapa tujuan yang dapat diperoleh dari pemberian motivasi yaitu :

1. Meningkatkan moral dan kepuasan kerja karyawan.

2. Meningkatkan prestasi kerja karyawan.

3. Meningkatkan kedisiplinan karyawan.

4. Mempertahankan kestabilan perusahaan.

5. Mengefektifkan pengadaan karyawan.

6. Menciptakan suasana dan hubungan kerja yang baik.

7. Meningkatkan loyalitas, kreatifitas dan partisipasi. 


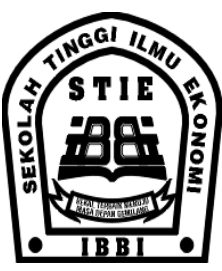

8. Meningkatkan tingkat kesejahteraan karyawan.

9. Meningkatkan rasa tanggung jawab karyawan terhadap tugas.

10. Meningkatkan efisiensi penggunaan alat-alat dan bahan baku.

Menurut Siagian (2015 : 294) faktorfaktor yang mempengaruhi motivasi kerja seseorang dapat diketahui berdasarkan karakteristik dari individu yang bersifat khas yang terdiri dari delapan faktor yaitu karakteristik biografi (yang meliputi usia, jenis kelamin, status perkawinan, jumlah tanggungan dan masa kerja), kepribadian, persepsi, kemampuan belajar, nilai - nilai yang dianut, sikap, kepuasan kerja dan kemampuan.

Menurut Sunyoto (2013 : 13), indikator motivasi kerja yang digunakan dalam penelitian ini yaitu :

1. Promosi

2. Prestasi Kerja

3. Pekerjaan itu sendiri

4. Penghargaan

5. Tanggung jawab

\section{Komunikasi}

Menurut Purwanto (2011 : 3), Komunikasi adalah suatu proses pertukaran informasi antar individu melalui suatu sistem yang biasa (lazim), baik dengan simbolsimbol, sinyal-sinyal, maupun perilaku atau tindakan.

Menurut Siagian (2015 : 308), dalam praktek terdapat empat arus komunikasi dalam suatu organisasi yaitu

1. Pertama : komunikasi vertikal ke bawah.

2. Kedua : Komunikasi vertikal ke atas.

3. Ketiga : Komunikasi horizontal.

4. Keempat : Komunikasi diagonal.

Menurut Siagian (2015 : 308), faktor yang mempengaruhi dalam suatu komunikasi :

1. Bahasa dan tulisan

2. Latar belakang budaya

3. Ikatan kelompok atau group

4. Harapan

5. Pendidikan

6. Situasi

Menurut Herlambang (2014 : 89), indikator komunikasi dalam penelitian ini adalah :
1. Keterbukaan
2. Empati
3. Dukungan
4. Kepositifan
5. Kesamaan

\section{Kinerja Karyawan}

Setiap perusahaan harus tetap survive dalam menjalankan usahanya. Untuk itu maka diperlukan kinerja karyawan sebagai salah satu faktor penting dalam menjalankan perusahaan. Menurut Bangun (2012 : 230) menyatakan kinerja karyawan adalah hasil pekerjaan yang dicapai seseorang berdasarkan persyaratanpersyaratan pekerjaan.

Menurut Hasibuan (2012 : 98) menyatakan bahwa faktor-faktor yang mempengaruhi kinerja karyawan yaitu bakat, pendidikan, pelatihan, lingkungan dan fasilitas, iklim kerja, gaji, bonus, interseleksi, motivasi, dan kemampuan hubungan industri, teknologi manajemen, kesempatan berprestasi, dan keberadaan pekerjaan yang mereka lakukan. Peningkatan kinerja karyawan tersebut maka yang menjadi tujuan perusahaan akan dapat tercapai. Sehingga dengan tercapainya tujuan perusahaan tersebut maka akan memberikan feedback (Umpan balik) yang positif bagi perusahaan itu sendiri.

Menurut Sedarmayanti (2014 : 197), indikator-indikator kinerja karyawan yang dapat memberi kontribusi kepada perusahaan antara lain :

1. Kualitas dari hasil.

2. Kuantitas dari hasil.

3. Ketepatan waktu dari hasil.

4. Sikap karyawan.

5. Kemampuan bekerja sama.

\section{Kerangka Pemikiran}

Motivasi kerja merupakan dorongan (ide, emosi atau kebutuhan fisik) yang menyebabkan seseorang mengambil suatu tindakan. Seseorang yang tidak termotivasi hanya memberikan upaya minimum dalam bekerja. Motivasi merupakan sebuah elemen penting dalam sebuah organisasi. Semakin besar promosi yang diperoleh maka semakin tinggi kualitas kerja karyawan, semakin besar 


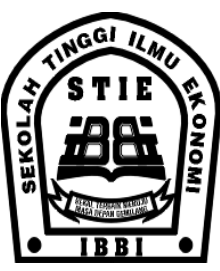

prestasi kerja maka semakin tinggi kuantitas kerja karyawan, semakin tinggi tantangan pekerjaan itu sendiri maka semakin tinggi ketetapan waktu penyelesaian kerja karyawan, semakin besar penghargaan yang diperoleh maka semakin baik sikap karyawan terhadap pekerjaan dan semakin tinggi tanggung jawab pekerjaan maka semakin tinggi juga kerjasama karyawan dalam menjalankan pekerjaan.

Komunikasi merupakan suatu proses penyampaian dan penerimaan berita atau informasi dari seseorang ke orang lain. Keberhasilan suatu organisasi sangat dipengaruhi oleh faktor komunikasi anggotaanggotanya dalam melakukan fungsinya masing-masing. Semakin besar keterbukaan informasi pekerjaan maka semakin tinggi kualitas kerja karyawan, semakin besar empati karyawan dalam berkomunikasi maka semakin tinggi kuantitas kerja karyawan, semakin besar dukungan terhadap karyawan untuk berkomunikasi maka semakin tinggi ketetapan waktu penyelesaian kerja karyawan, semakin besar karyawan menerima pesan yang positif maka semakin baik sikap karyawan terhadap pekerjaan dan semakin tinggi kesamaan karyawan menerima pesan maka semakin tinggi juga kerjasama karyawan dalam menjalankan pekerjaan.

Kinerja karyawan merupakan hasil kerja yang dicapai seseorang dalam melaksanakan tugas-tugas yang dibebankan kepadanya didasarkan atas kecakapan, pengalaman, kesungguhan serta waktu. Kinerja karyawan dapat meningkat apabila semakin tinggi motivasi kerja dan komunikasi.

Berdasarkan penjelasan di atas maka dapat digambarkan suatu hubungan antara motivasi kerja dan komunikasi dengan kinerja karyawan yang dapat dilihat pada gambar 1 .

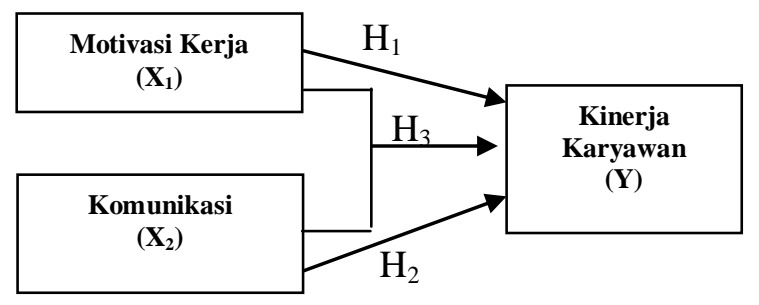

Gambar 1

Kerangka Pemikiran

\section{Hipotesis Penelitian}

Berdasarkan uraian kerangka pemikiran dan hasil kajian empiris diatas, maka beberapa hipotesis dalam penelitian ini sebagai berikut:

Menurut Hastuti (2013), Hasil pengujian menunjukan bahwa motivasi berpengaruh signifikan terhadap kinerja. Hal ini berarti bahwa jika motivasi pegawai meningkat, maka akan meningkatkan kinerja itu sendiri, sebaliknya jika motivasi turun, maka akan menurunkan kinerja. Seperti diketahui bahwa motivasi pegawai indikatornya berwujud keyakinan bahwa institusi tempat dia bekerja tersebut mampu memenuhi kebutuhan fisiologis akan menghasilkan penghargaan dan bisa diaktualisasikan dalam masyarakat. Keyakinan tersebut secara empiris memang mampu meningkatkan suasana dan kinerja lingkungan kantor. Temuan penelitian ini didukung penelitian Prabasari (2013) dan Shahzadi (2014)dengan menyatakan adanya hubungan secara signifikan antara motivasi kerja dan kinerja karyawan.

$\mathrm{H}_{1}$ : Motivasi Kerja berpengaruh terhadap kinerja karyawan pada PT. Indodacin Presisi Utama Medan.

Menurut Hastuti (2013), Hasil pengujian menunjukan bahwa komunikasi berpengaruh signifikan terhadap kinerja. Hal ini berarti bahwa jika kemampuan komunikasi pegawai meningkat, maka akan meningkatkan kinerja pegawai itu sendiri, sebaliknya jika kemampuan komunikasi pegawai turun, maka akan menurunkan kinerja pegawai. Temuan penelitian ini didukung penelitian Kusuma (2015), Prabasari (2013) dan Otieno (2015) dengan menyatakan adanya hubungan secara signifikan antara komunikasi dan kinerja karyawan.

$\mathrm{H}_{2}$ : Komunikasi berpengaruh terhadap kinerja karyawan pada PT. Indodacin Presisi Utama Medan.

Motivasi kerja dan komunikasi berpengaruh secara memiliki pengaruh terhadap kinerja karyawan. Hal ini ditandai apabila motivasi kerja meningkat dan komunikasi berjalan dengan lancar maka karyawan pada suatu perusahaan dapat meningkatkan kinerjanya.

$\mathrm{H}_{3}$ : Motivasi kerja dan komunikasi 


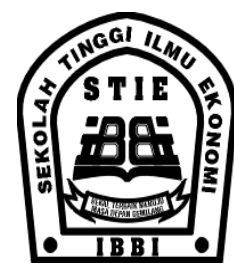

berpengaruh secara simultan terhadap kinerja karyawan pada PT. Indodacin Presisi Utama Medan.

\section{METODE PENELITIAN}

\section{Metode Yang Digunakan}

Penelitian ini menggunakan metode penelitian deskriptif kuantitatif. Metode ini bertujuan untuk menggambarkan tentang karakteristik dari suatu keadaan atau objek penelitian yang dilakukan melalui pengumpulan dan analisis data kuantitatif serta pengujian statistik dengan software SPSS.

\section{Operasional Variabel Penelitian}

Definisi Operasional Variabel terdiri dari dua variabel yaitu :

1. Variabel Independen $(\mathrm{X})$ :

a. Motivasi Kerja $\left(\mathrm{X}_{1}\right)$

Motivasi kerja merupakan do-rongan (ide, emosi atau kebutuhan fisik) yang menyebabkan seseorang mengambil suatu tindakan.

b. Komunikasi $\left(\mathrm{X}_{2}\right)$

Komunikasi merupakan suatu pro-ses penyampaian dan penerimaan berita atau informasi dari seseorang ke orang lain.

2. Variabel Dependen (Y): Kinerja Karyawan.

Kinerja karyawan merupakan hasil kerja yang dicapai seseorang dalam melaksanakan tugas-tugas yang dibebankan kepadanya didasarkan atas kecakapan, pengalaman, kesungguhan serta waktu.

\section{Populasi dan Sampel Penelitian}

Populasi pada penelitian ini dilakukan pada PT. Indodacin Presisi Utama Medan yang berjumlah 42 orang karyawan yang terdiri dari karyawan di kantor dan teknisi PT. Indodacin Presisi Utama Medan. Pada penentuan responden yang akan dijadikan sampel, penulis menggunakan teknik sampel jenuh, yaitu teknik penentuan sampel bila semua anggota digunakan sebagai sampel sehingga peneliti mengambil sampel pada seluruh karyawan yang bekerja pada PT. Indodacin Presisi Utama Medan berjumlah 42 orang.

\section{Uji Validitas dan Reliabilitas}

Menurut Ghozali (2009 : 49), suatu kuesioner dikatakan valid dan reliabel jika pertanyaan pada kuesioner mampu untuk mengungkapkan sesuatu yang akan diukur oleh kuesioner tersebut. Sedangkan menurut Ghozali (2009 : 45), reliabilitas sebenarnya adalah alat untuk mengukur suatu kuesioner yang merupakan indikator dari variabel atau konstruksi.

\section{Teknik Analisa Data}

1. Uji Asumsi Klasik

a. Uji Normalitas

Menurut Ghozali (2009 : 147), uji normalitas adalah untuk mengetahui apakah distribusi sebuah data mengikuti atau mendekati distribusi normal.

b. Uji Multikolinieritas

Menurut Ghozali (2009 : 95), multikolinieritas berarti adanya hubungan linier yang sempurna atau pasti di antara beberapa atau semua variabel yang menjelaskan dari model regresi.

c. Uji Heteroskedastisitas

Menurut Ghozali (2009 : 126), uji ini pada prinsipnya adalah ingin menguji apakah sebuah grup mempunyai varians yang sama di antara anggota grup tersebut.

\section{Model Analisis Data}

Model Analisis Data ini menggunakan analisis regresi linier berganda. Model regresi yang digunakan adalah :

$$
\mathrm{Y}=\mathrm{a}+\mathrm{b}_{1} \mathrm{X}_{1}+\mathrm{b}_{2} \mathrm{X}_{2}+\mathrm{e}
$$

Keterangan :

$$
\begin{array}{ll}
\mathrm{Y} & =\text { Kinerja Karyawan } \\
\mathrm{a} & =\text { konstanta } \\
\mathrm{X}_{1} & =\text { Motivasi Kerja } \\
\mathrm{X}_{2} & =\text { Komunikasi } \\
\mathrm{b}_{1}, \mathrm{~b}_{2} & =\text { Koefisien regresi } \\
\mathrm{e} & =\text { Standar error (tingkat kesalahan) }
\end{array}
$$

3. Pengujian Hipotesis

a. Uji signifikansi parsial (t-test)

Pengujian t-test digunakan untuk mengetahui ada tidaknya hubungan atau pengaruh yang berarti (signifikan) antara variabel independen secara parsial terhadap variabel dependen. 


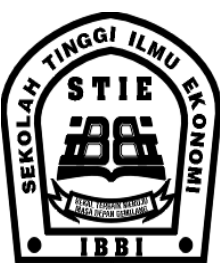

b. Uji signifikansi simultan (F-test)

Pengujian F-test ini dilakukan untuk mengetahui pengaruh antara variabel independen terhadap variabel dependen secara bersama-sama.

\section{c. Koefisien Determinasi $\left(\mathrm{R}^{2}\right)$}

Koefisien Determinasi $\left(\mathrm{R}^{2}\right)$ ditujukan untuk mengetahui seberapa besar kemampuan model dalam menerangkan variabel dependen.

\section{HASIL DAN PEMBAHASAN} Analisis Regresi Linear Berganda

Analisis regresi linear berganda digunakan untuk memprediksi nilai dari variabel terikat dengan memperhatikan variabel bebas. Tabel 4 berikut ini menunjukkan hasil estimasi regresi melalui pengolahan data dengan bantuan program software SPSS For Windows versi 20.0 .

Tabel 3

Hasil Analisis Regresi Linear Berganda

\begin{tabular}{|l|r|r|r|}
\hline Model & \multicolumn{2}{|c|}{$\begin{array}{c}\text { Unstandardized } \\
\text { Coefficients }\end{array}$} & $\begin{array}{c}\text { Standardiz } \\
\text { ed } \\
\text { Coefficients }\end{array}$ \\
\cline { 2 - 4 } & \multicolumn{1}{|c|}{ B } & Std. Error & \multicolumn{1}{c|}{ Beta } \\
\hline (Constant) & .375 & 1.465 & \\
1 Motivasi Kerja & .446 & .106 & .456 \\
Komunikasi & .535 & .115 & .504 \\
\hline
\end{tabular}

Sumber : Hasil data Olahan SPSS, 2017

Pengolahan data tersebut menghasilkan suatu persamaan analisis regresi linear berganda sebagai berikut :

$$
Y=0,375+0,446 X_{1}+0,535 X_{2}
$$

Penjelasan dari persamaan regresi berganda tersebut dapat dijelaskan dibawah ini.

1. Nilai Konstanta sebesar 0,375 menunjukkan bahwa apabila tidak ada variabel independen atau variabel independen dianggap nol, maka kinerja karyawan memiliki nilai sebesar 0,375 .

2. Nilai koefisien regresi motivasi kerja $\left(X_{1}\right)=$ 0,446 menunjukkan hubungan yang positif artinya setiap variabel motivasi kerja meningkat sebesar satu satuan, maka kinerja karyawan akan meningkat sebesar 0,446 satuan dengan asumsi variabel komunikasi lainnya dan nilai konstanta sama dengan nol.
3. Nilai koefisien regresi komunikasi $\left(\mathrm{X}_{2}\right)=$ 0,535 menunjukkan hubungan yang positif dimana setiap variabel komunikasi meningkat sebesar satu satuan, maka kinerja karyawan akan meningkat sebesar 0,535 satuan dengan asumsi variabel motivasi kerja lainnya dan nilai konstanta sama dengan nol.

\section{Pengujian Hipotesis}

Pengujian hipotesis ini dilakukan dengan menggunakan SPSS versi 20.0 dan pengujian ini terdiri dari :

1. Uji t

Uji $\mathrm{t}$ bertujuan untuk membuktikan pengaruh variabel independen terhadap variabel dependen dan hasil pengujian secara parsial dapat dilihat pada Tabel 4 berikut :

\section{Tabel 4}

\section{Hasil Uji t}

\begin{tabular}{|rl|r|r|}
\hline Model & & \multicolumn{1}{c|}{$\mathrm{t}$} & \multicolumn{1}{c|}{ Sig. } \\
\hline \multirow{3}{*}{1} & (Constant) & .256 & .799 \\
& Motivasi Kerja & 4.220 & .000 \\
& Komunikasi & 4.663 & .000 \\
\hline
\end{tabular}

Sumber : Hasil data Olahan SPSS, 2017

Untuk variabel motivasi kerja, nilai $\mathrm{t}_{\text {hitung }}$ $(4,220)$ lebih besar dengan nilai $t_{\text {tabel }}(2,022)$ dan nilai signifikansi $(0,000)$ lebih kecil dari alpha $(0,05)$ menyatakan bahwa $\mathrm{H}_{1}$ diterima yang artinya motivasi kerja berpengaruh signifikan secara parsial terhadap kinerja karyawan PT. Indodacin Presisi Utama Medan.

Untuk variabel komunikasi, nilai $\mathrm{t}_{\text {hitung }}$ $(4,663)$ lebih besar dengan nilai $t_{\text {tabel }}(2,022)$ dan nilai signifikansi $(0,000)$ lebih kecil dari alpha $(0,05)$ menyatakan bahwa $\mathrm{H}_{2}$ diterima yang artinya komunikasi berpengaruh signifikan secara parsial terhadap kinerja karyawan PT. Indodacin Presisi Utama Medan.

\section{Uji F}

Uji - F pada dasarnya menunjukkan apakah semua variabel yang dimasukkan dalam model mempunyai pengaruh secara bersama-sama terhadap variabel dependen dapat dilihat pada Tabel 5 berikut :

\section{Tabel 5}

Hasil Uji - F 

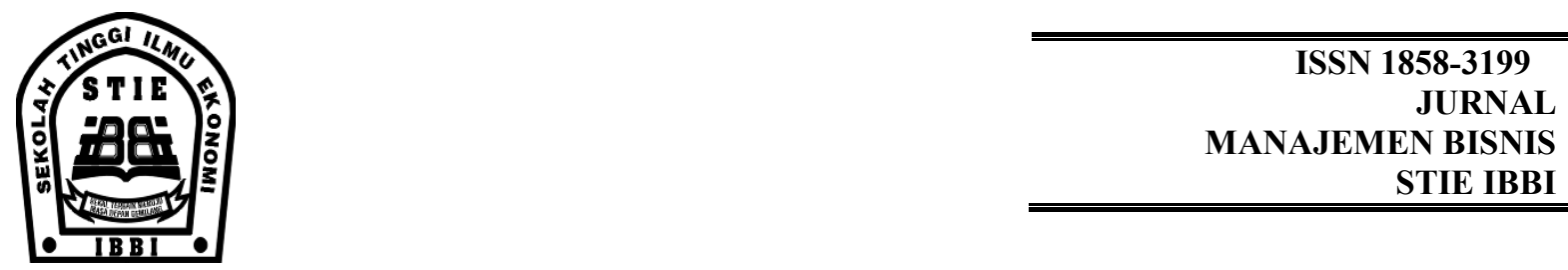

MANAJEMEN BISNIS

STIE IBBI

\begin{tabular}{|l|r|r|r|c|c|}
\hline Model & $\begin{array}{c}\text { Sum of } \\
\text { Squares }\end{array}$ & df & $\begin{array}{c}\text { Mean } \\
\text { Square }\end{array}$ & F & Sig. \\
\hline Regression & 386.236 & 2 & 193.118 & 90.636 & $.000^{\mathrm{b}}$ \\
1 Residual & 83.097 & 39 & 2.131 & & \\
Total & 469.333 & 41 & & & \\
\hline
\end{tabular}

a. Dependent Variable: Kinerja Karyawan

b. Predictors: (Constant), Komunikasi, Motivasi Kerja

Tabel 5 diperoleh nilai $\mathrm{F}_{\text {hitung }}$ pada hasil uji $\mathrm{F}$ sebesar 90,636 dengan tingkat signifikan sebesar 0,000. Nilai $F_{\text {tabel }}$ dapat dicari pada lampiran tabel $\mathrm{F}$ dengan df $1=2$ dan df $2=39$ sehingga diperoleh nilai $F_{\text {tabel }}(0,05,2,39)$ sebesar 3,24 dengan hasil tersebut dimana $\mathrm{F}_{\text {hitung }}$ lebih besar dari $\mathrm{F}_{\text {tabel }}$ dan nilai signifikan yang lebih kecil dari pada alpha 5\% maka hasil penelitian ini menyatakan $\mathrm{H}_{3}$ diterima dengan kesimpulan adalah secara simultan motivasi kerja dan komunikasi berpengaruh signifikan secara simultan terhadap kinerja karyawan pada PT. Indodacin Presisi Utama Medan.

\section{Koefisien Determinasi}

Nilai koefisien determinasi dilihat pada Adjusted $R$ Square yang bertujuan untuk mengukur besarnya koefisien variabel independen menjelaskan pengaruhnya terhadap variabel dependen.

\section{Tabel 6}

Hasil Koefisien Determinasi Model Summary ${ }^{\mathrm{D}}$

\begin{tabular}{|l|c|r|c|c|}
\hline $\begin{array}{l}\text { Mod } \\
\text { el }\end{array}$ & $\mathrm{R}$ & $\begin{array}{c}\mathrm{R} \\
\text { Square }\end{array}$ & $\begin{array}{l}\text { Adjusted R } \\
\text { Square }\end{array}$ & $\begin{array}{c}\text { Std. Error } \\
\text { of the } \\
\text { Estimate }\end{array}$ \\
\hline 1 & $.907^{\mathrm{a}}$ & .823 & .814 & 1.460 \\
\hline
\end{tabular}
a. Predictors: (Constant), Komunikasi, Motivasi Kerja
b. Dependent Variable: Kinerja Karyawan
Sumber : Hasil data Olahan SPSS, 2017

Berdasarkan Tabel 6 diperoleh nilai koefisien determinasi yang dilihat dari Adjusted $R$ Square sebesar 0,814. Artinya kemampuan variabel motivasi kerja dan komunikasi mampu menjelaskan terhadap kinerja karyawan sebesar $81,4 \%$. Sedangkan sisanya sebesar $18,6 \%$ merupakan variabel independen lain yang tidak diteliti dalam penelitian ini seperti disiplin kerja dan pelatihan kerja.

\section{Pembahasan Hasil Penelitian}

Berdasarkan pengujian hipotesis secara parsial dapat diketahui bahwa variabel motivasi kerja memiliki nilai $t_{\text {hitung }}(4,220)$ lebih besar dengan nilai $t_{\text {tabel }}(2,022)$ dan nilai signifikansi $(0,000)$ lebih kecil dari alpha $(0,05)$. Artinya bahwa motivasi kerja berpengaruh signifikan terhadap kinerja karyawan pada PT. Indodacin Presisi Utama Medan. Hasil ini sejalan dengan pendapat Hasibuan (2012 : 141) yang mengatakan motivasi yaitu bagaimana caranya mendorong gairah kerja bawahan agar mereka mau bekerja keras dengan memberikan semua kemampuan dan keterampilannya untuk mewujudkan tujuan organisasi. Motivasi sangat penting karena dengan motivasi ini diharapkan setiap karyawan mau bekerja keras. Hal ini berarti bahwa jika motivasi pegawai meningkat, maka akan meningkatkan kinerja itu sendiri, sebaliknya jika motivasi turun, maka akan menurunkan kinerja. Hasil penelitian ini juga menunjukkan bahwa di PT. Indodacin Presisi Utama Medan, seluruh karyawan memperoleh kesempatan yang sama untuk mendapatkan promosi jabatan dan karyawan dapat meningkatkan prestasi kerja saya sesuai dengan standar kerja perusahaan. Hal ini sejalan dengan penelitian Hastuti (2013), Prabasari (2013) dan Shahzadi (2014) dengan menyatakan adanya hubungan secara signifikan antara motivasi kerja dan kinerja karyawan.

Berdasarkan pengujian hipotesis secara parsial dapat diketahui bahwa variabel komunikasi memiliki nilai $t_{\text {hitung }}(4,663)$ lebih besar dengan nilai $t_{\text {tabel }}(2,022)$ dan nilai signifikansi $(0,000)$ lebih kecil dari alpha $(0,05)$. Artinya bahwa komunikasi berpengaruh signifikan terhadap kinerja karyawan pada PT. Indodacin Presisi Utama Medan. Hasil ini sejalan dengan pendapat Herlambang (2014 : 77) yang mengatakan bahwa komunikasi adalah suatu proses penyampaian dan penerimaan berita atau informasi dari seseorang ke orang lain. Komunikasi sangat penting karena dengan komunikasi yang lancar diharapkan kegiatan perusahaan berjalan dengan baik. Hal ini berarti bahwa jika komunikasi baik, maka akan meningkatkan kinerja itu sendiri, sebaliknya 


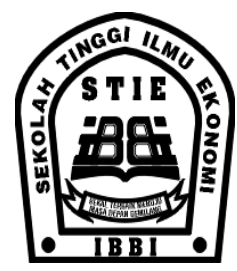

jika komunikasi buruk, maka akan menurunkan kinerja. Hasil penelitian ini juga menunjukkan bahwa sewaktu bekerja, pesan yang disampaikan mampu dipahami dan memotivasi karyawan dalam mengerjakan pekerjaan, pesan yang disampaikan oleh pimpinan kepada karyawan adalah benar dan akurat sehingga dapat membantu menyelesaikan pekerjaan dan setiap hari karyawan selalu menunjukkan rasa kebersamaan dalam berkomunikasi sehingga dapat meningkatkan kinerja karyawan. Hal ini sejalan dengan penelitian Hastuti (2013), Kusuma (2015), Prabasari (2013) dan Otieno (2015) dengan menyatakan adanya hubungan secara signifikan antara komunikasi dan kinerja karyawan.

Berdasarkan pengujian hipotesis secara simultan dapat dilihat pada tabel hasil nilai $F_{\text {hitung }}$ sebesar 90,636 lebih besar dari $F_{\text {tabel }}$ sebesar 3,24 dengan tingkat signifikan sebesar 0,000 lebih kecil dari 0,05 maka hasil penelitian ini menyatakan kesimpulan adalah secara simultan motivasi kerja dan komunikasi berpengaruh signifikan terhadap kinerja karyawan pada PT. Indodacin Presisi Utama Medan.

Hasil ini sejalan dengan pendapat Menurut Hasibuan (2012 : 94) menjelaskan bahwa kinerja merupakan hasil kerja yang dicapai seseorang dalam melaksanakan tugastugas yang dibebankan kepadanya didasarkan atas kecakapan, pengalaman, kesungguhan serta waktu. Hal ini berarti bahwa jika motivasi kerja tinggi dan komunikasi baik, maka akan meningkatkan kinerja itu sendiri, sebaliknya jika motivasi kerja rendah dan komunikasi buruk, maka akan menurunkan kinerja. Hasil penelitian ini juga menunjukkan bahwa karyawan selalu dapat menyelesaikan pekerjaan tepat waktu dan karyawan mampu bekerja dengan teliti, cepat dan tepat sesuai dengan target yang telah ditentukan PT. Indodacin Presisi Utama Medan. Hasil ini uji statistik ini bisa dilihat juga pada besarnya nilai koefisien determinasi yang dilihat dari Adjusted $R$ Square sebesar 0,814. Artinya kemampuan variabel motivasi kerja dan komunikasi mampu menjelaskan terhadap kinerja karyawan sebesar $81,4 \%$. Sedangkan sisanya sebesar $18,6 \%$ merupakan variabel bebas lain yang tidak diteliti dalam penelitian ini seperti disiplin kerja dan pelatihan kerja.

\section{KESIMPULAN DAN SARAN Kesimpulan}

Berdasarkan hasil penelitian, maka kesimpulan yang diperoleh yaitu :

1. Secara parsial, motivasi kerja berpengaruh signifikan terhadap kinerja karyawan pada PT. Indodacin Presisi Utama Medan.

2. Secara parsial, komunikasi berpengaruh signifikan terhadap kinerja karyawan pada PT. Indodacin Presisi Utama Medan.

3. Dan secara simultan, motivasi kerja dan komunikasi berpengaruh signifikan terhadap kinerja karyawan pada PT. Indodacin Presisi Utama Medan. Besarnya koefisien determinasi dilihat dari Adjusted $R$ Square sebesar 0,814. Artinya kemampuan variabel motivasi kerja dan komunikasi mampu menjelaskan terhadap kinerja karyawan sebesar $81,4 \%$. Sedangkan sisanya sebesar 18,6\% merupakan variabel bebas lain yang tidak diteliti dalam penelitian ini seperti disiplin kerja dan pelatihan kerja.

\section{Saran}

Berdasarkan hasil penelitian dan kesimpulan diatas, maka peneliti perlu memberikan saran-saran, antara lain:

1. Untuk item motivasi kerja yang dinilai berpengaruh terhadap kinerja karyawan, karyawan merasa tertantang untuk menyelesaikan setiap pekerjaan yang diberikan oleh perusahaan, karyawan memperoleh penghargaan oleh perusahaan atas prestasi kerja dan karyawan bertanggung jawab atas suatu tugas atau pekerjaan yang dikerjakan harus ditingkatkan manajemen perusahaan dengan cara menyesuaikan tantangan pekerjaan dengan kemampuan karyawan dan menetapkan standar kerja perusahaan setiap hari agar dapat lebih meningkatkan pengaruhnya pada kinerja karyawan.

2. Untuk item komunikasi yang dinilai berpengaruh terhadap kinerja karyawan, 


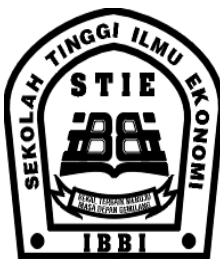

pimpinan secara terbuka menjelaskan pekerjaan yang akan dilakukan kepada karyawan dan pimpinan memberikan dukungan kepada karyawan untuk berbicara harus ditingkatkan manajemen perusahaan dengan cara meningkatkan keterbukaan komunikasi terhadap karyawan dalam hal menjalankan pekerjaan dan memberikan kebebasan pada karyawan untuk berbicara agar dapat lebih meningkatkan pengaruhnya pada kinerja karyawan.

3. Untuk peneliti selanjutnya yang melakukan penelitian dengan topik yang sama agar menambah jumlah variabel penelitian yang mempengaruhi kinerja karyawan seperti disiplin kerja dan pelatihan kerja.

\section{DAFTAR PUSTAKA}

Bangun, Wilson. 2012. Manajemen Sumber Daya Manusia. Bandung : Erlangga.

Ghozali, Imam. 2009. Aplikasi Analisis Multivariate dengan Program SPSS. Semarang: Universitas Diponegoro.

Hasibuan, Melayu. 2012. Manajemen Sumber Daya Manusia. Jakarta : Bumi Aksara.

Hastuti, Sri. 2013. Pengaruh Komunikasi, Motivasi Dan Etos Kerja Terhadap Kinerja Pegawai Koordinator Unit Pelaksana Teknis Dinas Pendapatan Provinsi Jawa Timur Di Probolinggo. ISSN : 1412-5366. JEAM Vol XII No. 1/2013. Surabaya : Universitas Jember.

Herlambang, Susatyo. 2013. Pengantar Manajemen. Yogyakarta : Gosyen Publishing.
2014. Perilaku Organisasi. Yogyakarta : Gosyen Publishing.

Kusuma, Galih Candra. 2015. Pengaruh Motivasi Dan Pelatihan Terhadap Kinerja (Studi pada Karyawan PT.PLN (Persero) Distribusi Jawa Timur Area Malang). Jurnal Administrasi Bisnis. JAB, Vol. 21 No. 1 April 2015. Malang : Universitas Brawijaya.

Prabasari, I Gusti Agung Ayu Maya. 2013. Pengaruh Motivasi, Disiplin Kerja Dan Komunikasi Terhadap Kinerja Karyawan Pada PT. PLN (Persero) Distribusi Bali. ISSN: 2302-8912. Jurnal Manajemen Universitas Udayana, Vol 2, No 4 (2013). Bali : Universitas Udayana (Unud).

Purwanto, D. 2011. Komunikasi Bisnis. Edisi ke 4. Jakarta : Erlangga.

Otieno, Brenda Beryl Achieng. 2015. Effect of Employee Communication on Organisation Performance in Kenya's Horticultural Sector. Vol. 6, No. 2; 2015. Kenya : Jomo Kenyatta University.

Sedarmayanti. 2014. Manajemen Sumber Daya Manusia. Jakarta : Refika Aditama.

Shahzadi, Irum. 2014. Impact of Employee Motivation on Employee Performance. Vol.6, No.23, 2014. Pakistan : The Islamia University of Bahawalpur.

Siagian, Sondang P. 2015. Manajemen Sumber Daya Manusia. Jakarta: Bumi Aksara.

Sunyoto, Danang. 2013. Sumber Daya Manusia : Teori, Kuesioner dan Analisa Data. Jakarta : PT CAPS. 